\title{
Physiological Patterns of Electrical Stimulation Can Induce Neuronal Gene Expression by Activating N-Type Calcium Channels
}

\author{
Teresa A. Brosenitsch and David M. Katz \\ Department of Neurosciences, Case Western Reserve University School of Medicine, Cleveland, Ohio 44106
}

Activity-dependent neuronal gene expression is thought to require activation of L-type calcium channels, a view based primarily on studies in which chronic potassium $\left(\mathrm{K}^{+}\right)$depolarization was used to mimic neuronal activity. However, N-type calcium channels are primarily inactivated during chronic depolarization, and their potential contribution to gene expression induced by physiological patterns of stimulation has not been defined. In the present study, electrical stimulation of dissociated primary sensory neurons at $5 \mathrm{~Hz}$, or treatment with elevated $\mathrm{K}^{+}$, produced a large increase in the percentage of neurons that express tyrosine hydroxylase (TH) mRNA and protein. However, blockade of L-type channels, which completely inhibited $\mathrm{K}^{+}$-induced expression, had no effect on $\mathrm{TH}$ expression induced by patterned stimulation. Conversely, blockade of $\mathrm{N}$-type channels completely inhibited $\mathrm{TH}$ induction by patterned stimulation, whereas $\mathrm{K}^{+}$-induced expression was unaffected. Similar results were obtained for depolarization-

Activity-dependent, calcium-regulated gene expression plays a critical role in diverse neural functions, including differentiation (Gu and Spitzer, 1997; Buonanno and Fields, 1999) and survival (Ghosh et al., 1994) of neurons, formation of synaptic connections (Lein and Shatz, 2000), and learning and memory (Svoboda and Mainen, 1999). The importance of calcium-regulated gene expression has led to numerous studies examining molecular mechanisms that link membrane depolarization, and subsequent elevation of intracellular calcium levels, with gene expression (Finkbeiner and Greenberg, 1998). One conclusion of these studies is that activation of L-type calcium channels is required for depolarization-mediated gene induction.

Most studies that have examined mechanisms of activitydependent gene expression have used chronic membrane depolarization, induced by elevated $\mathrm{K}^{+}$or glutamate, to raise intracellular calcium levels and stimulate gene expression. Although these methods are effective at elevating intracellular calcium, they produce a nonphysiological chronic membrane depolarization and tonic elevation of intracellular calcium, conditions that do not mimic cellular responses to physiological patterns of phasic neuronal activity. In fact, the importance of patterned stimulation, or

Received Nov. 20, 2000; revised Jan. 16, 2001; accepted Jan. 24, 2001.

This work was supported by National Institutes of Health Grants HL25830 (Project 2; to D.M.K.) and 5T32NS07118. We thank Drs. Lynn Landmesser, Gary Landreth, Evan Deneris, Vance Lemmon, and Karl Herrup for their very helpful discussions of this work. We also thank Drs. R. Douglas Fields and Agnieszka Balkowiec for advice regarding electrical field stimulation of neuronal cultures.

Correspondence should be addressed to Dr. David M. Katz, Department of Neurosciences, Case Western Reserve University School of Medicine, 10900 Euclid Avenue, Cleveland, OH 44106. E-mail: dmk4@po.cwru.edu.

Copyright (C) 2001 Society for Neuroscience $0270-6474 / 01 / 212571-09 \$ 15.00 / 0$ induced expression of the immediate early genes Nurr1 and Nur77. In addition, TH induction by patterned stimulation was significantly reduced by inhibitors of PKA and PKC but was unaffected by inhibition of the mitogen-activated protein kinase (MAPK) pathway. On the other hand, $\mathrm{K}^{+}$-induced TH expression was significantly reduced by inhibition of the MAPK pathway but was unaffected by inhibitors of PKA or PKC. These results demonstrate that $\mathrm{N}$-type calcium channels can directly link phasic membrane depolarization to gene expression, challenging the view that activation of L-type channels is required for nuclear responses to physiological patterns of activity. Moreover, our data show that phasic and chronic depolarizing stimuli act through distinct mechanisms to induce neuronal gene expression.

Key words: activity-dependent gene expression; PKA; PKC; CREB; Nurr1; dopamine

oscillating levels of intracellular calcium, in mediating gene expression (Fields et al., 1997; Dolmetsch et al., 1998; Li et al., 1998), neurotrophin release (Balkowiec and Katz, 2000), and neuronal differentiation ( $\mathrm{Gu}$ and Spitzer, 1997) is clear. For example, Fields and colleagues (1997) demonstrated that the level of $c$-fos expression in primary sensory neurons is correlated with the time interval between bursts of action potentials rather than with the amplitude of calcium influx. In addition, Balkowiec and Katz (2000) demonstrated recently that, although short-term continuous membrane depolarization is completely ineffective at releasing brain-derived neurotrophic factor from primary sensory neurons, patterned stimulation for the same period of time increases release 20 -fold. Thus, the use of chronic stimulation as a model for neuronal activity is unlikely to provide a complete understanding of mechanisms that underlie activity-dependent signaling events.

We demonstrated previously that activation of L-type calcium channels by chronic $\mathrm{K}^{+}$depolarization alters short- and longterm regulation of tyrosine hydroxylase $(\mathrm{TH})$ expression in primary sensory neurons, despite the fact that N-type calcium channels carry the majority of the voltage-activated calcium current in these cells (Brosenitsch et al., 1998). However, under conditions of sustained membrane depolarization, N-type calcium channels are inactivated (Nowycky et al., 1985; Hirning et al., 1988) and their potential contribution to activity-dependent events cannot be evaluated. Therefore, in the present study, we evaluated the role of $\mathrm{N}$ - and L-type calcium channels in activity-dependent gene expression by comparing the effects of $\mathrm{K}^{+}$depolarization and patterned electrical field stimulation. Our findings demonstrate that, in sharp contrast to chronic membrane depolarization, 
patterned electrical stimulation acts through N-type calcium channels to induce neuronal gene expression. Moreover, we show that expression induced by electrical stimulation requires activation of intracellular protein kinase pathways distinct from those activated by chronic $\mathrm{K}^{+}$depolarization.

\section{MATERIALS AND METHODS}

Cell culture. Pregnant dams (Sprague Dawley rat; Zivic-Miller, Zelienople, PA) were rapidly killed by exposure to carbon dioxide. The uterine horns were removed and placed into PBS containing $10 \%$ glucose, and the embryos were excised. To assign gestational ages, the day after mating was designated embryonic day (E) 0.5. E16.5 petrosal ganglia (PG) were digested in Dispase (Roche Molecular Biochemicals, Mannheim, Germany) for $30 \mathrm{~min}$ at $37^{\circ} \mathrm{C}$, followed by trituration through siliconized, fire-polished Pasteur pipettes. Cells were plated onto glass coverslips coated with Growth Factor Reduced Matrigel Matrix (diluted 1:10; Becton Dickinson, Bedford, MA) at a density of one ganglion per well. Dissociate cultures were grown in Neurobasal medium supplemented with B-27 serum-free supplement, $1 \%$ penicillin-streptomycinneomycin antibiotic mixture, and $0.5 \mathrm{~mm}$ L-glutamine (Life Technologies, Gaithersburg, MD). All cultures were supplemented with recombinant human brain-derived neurotrophic factor (a gift from Regeneron Pharmaceuticals Inc., Tarrytown, NY) at a concentration of $10 \mathrm{ng} / \mathrm{ml}$. Neurons were cultured for a total of $4 \mathrm{~d}$ before stimulation for 6 or $24 \mathrm{hr}$ with either $40 \mathrm{~mm} \mathrm{KCl}$ or patterned electrical impulses (see below). For experiments examining TH protein expression, the medium was replaced immediately after stimulation, and the cultures were grown for an additional $12 \mathrm{hr}$ in control conditions to permit new protein synthesis. For experiments examining TH mRNA or Nur-related factor (Nurr) expression, cultures were fixed immediately after stimulation.

Stimulation protocols and reagents. PG cultures were electrically stimulated in 24-well plates fitted with a pair of platinum electrodes connected in parallel to a stimulator (MultiStim System; Digitimer, Hertfordshire, UK). Cultures were stimulated with $0.2 \mathrm{msec}$ pulses of alternating polarity delivered at $5 \mathrm{~Hz}$ continuously or at $25 \mathrm{~Hz}$ in 2 -sec-long bursts delivered once every $10 \mathrm{sec}$. These two stimulation paradigms produce an equivalent number of pulses over the $6 \mathrm{hr}$ stimulation period. The drugs used are as follows. $\omega$-Conotoxin GVIA (Sigma, St. Louis, MO) and tetrodotoxin (Sigma) were used at final concentrations of 1 and $1.5 \mu \mathrm{M}$, respectively. Nimodipine (Sigma), dissolved in methanol, was used at a final concentration of $2 \mu \mathrm{M}$. PD98059 (Calbiochem, La Jolla, CA) and H-89 (Calbiochem), dissolved in dimethylsulfoxide (DMSO), were used at final concentrations of 50 and $3 \mu \mathrm{M}$, respectively. Membrane-permeable forms of the protein kinase A (PKA) inhibitor $\mathrm{PKI}_{14-22}$ amide-myristoylated (Calbiochem), the protein kinase $\mathrm{C}$ (PKC) inhibitor PKC-I ${ }_{19-27}$-myristoylated (Calbiochem), and the calcium/calmodulin kinase (CaMK) II inhibitor autocamtide-2 inhibitory peptide-myristoylated (Calbiochem) were used at a final concentration of $50 \mu \mathrm{m}$. These concentrations of kinase inhibitors have been shown previously to be efficacious and specific (Eichholtz et al., 1993; Alessi et al., 1995; Ishida et al., 1995; Harris et al., 1997). Actinomycin D (Sigma) was used at a final concentration of $0.5 \mu \mathrm{g} / \mathrm{ml}$. D,L-2-Amino-5phosphonovaleric acid (APV) (Sigma) was used at a concentration of 50 $\mu$ M. 6-Cyano-7-nitroquinoxaline-2,3- $(1 \mathrm{H}, 4 \mathrm{H})$-dione (CNQX) (Sigma) was dissolved in DMSO and used at a final concentration of $10 \mu \mathrm{M}$. In each experiment, the final DMSO concentration never exceeded $0.02 \%$. Pertussis toxin (Calbiochem) was used at a final concentration of 1 $\mu \mathrm{g} / \mathrm{ml}$, and cultures were preincubated with the toxin for $20 \mathrm{hr}$ before the onset of stimulation.

Immunocytochemistry. All cultures were fixed with $4 \%$ paraformaldehyde in $0.1 \mathrm{M}$ sodium phosphate buffer (PFA), $\mathrm{pH} 7.4$, for $30 \mathrm{~min}$. The following antibodies were used for double-immunostaining: polyclonal anti-TH (Pel-Freez Biologicals, Rogers, AR), polyclonal anti-Nurr1/ Nur77 (Santa Cruz Biotechnology, Santa Cruz, CA), polyclonal antiphosphorylated cAMP response element-binding protein (pCREB) (Upstate Biotechnology, Lake Placid, NY), monoclonal anti-neurofilament (NF) protein $\left(\mathrm{NF}_{160,68}\right.$; Sigma), goat anti-rabbit IgG-FITC (Roche Molecular Biochemicals), and goat anti-mouse $\mathrm{IgG}$ rhodamine (Cappel, Durham, NC). TH-NF immunostaining was performed as described previously (Brosenitsch et al., 1998). The protocol for Nurr and pCREB immunostaining was the same as for TH-NF, except that cells were incubated in $20 \%$ goat serum in PBS containing $0.5 \%$ Triton X-100 (PBS-Tx) before incubation in the primary antibodies, which was per- formed at $4^{\circ} \mathrm{C}$ in anti-Nurr1/Nur77 (1:4000) or anti-pCREB (1:2000) and anti-NF (1:100) diluted in PBS-Tx containing $2 \%$ goat serum.

In situ hybridization. The digoxigenin (DIG)-labeled $\mathrm{TH}$ sense and antisense RNA probes were prepared using as template a $280 \mathrm{bp}$ fragment of TH cDNA (1240-1521) cloned into the EcoRI site of pGEM-3 phagemid [generated in the laboratory of A. William Tank, University of Rochester School of Medicine and Dentistry (Rochester, NY), and generously provided by Kumi Nagomoto-Combs, Case Western Reserve University]. Sense and antisense probes were synthesized with DIG-11UTP (Roche Molecular Biochemicals) using an RNA transcription kit (Stratagene, La Jolla, CA). For hybridization, cultures were fixed in PFA for $30 \mathrm{~min}$, rinsed twice in PBS, acetylated with $0.25 \%$ acetic anhydride in $10 \mathrm{~mm}$ triethanolamine, $\mathrm{pH} 8.0$, for $10 \mathrm{~min}$, rinsed in $1 \times \mathrm{SSC}$ for 10 min, and incubated in hybridization buffer $(50 \%$ formamide, $5 \times$ SSC, 1 $\mathrm{mg} / \mathrm{ml}$ yeast tRNA, $100 \mu \mathrm{g} / \mathrm{ml}$ heparin, $1 \times$ Denhardt's reagent, $0.1 \%$ Tween 20, $1 \mathrm{mg} / \mathrm{ml}$ 3-[(3-cholamidopropyl)dimethylammonio]-1-propanesulfonate, and $5 \mathrm{~mm}$ EDTA) without probe for $6 \mathrm{hr}$. Sense and antisense probes were diluted 1:40 in hybridization buffer, and cultures were hybridized for $16 \mathrm{hr}$ at $50^{\circ} \mathrm{C}$. After hybridization, cultures were washed in $1 \times \mathrm{SSC}$ at $60^{\circ} \mathrm{C}$ for $10 \mathrm{~min}$ and again for $30 \mathrm{~min}$, washed in $0.1 \times \mathrm{SSC}$ for $1 \mathrm{hr}$ at $60^{\circ} \mathrm{C}$, incubated in $20 \mu \mathrm{g} / \mathrm{ml} \mathrm{RNase} \mathrm{A}$ at $37^{\circ} \mathrm{C}$ for $30 \mathrm{~min}$, rinsed in $1 \mathrm{~mm}$ dithiothreitol at $37^{\circ} \mathrm{C}$ for $30 \mathrm{~min}$, washed in $0.1 \times \mathrm{SSC}$ for $1 \mathrm{hr}$ at $65^{\circ} \mathrm{C}$, and washed in $2 \times \mathrm{SSC}$ for $30 \mathrm{~min}$. For immunological detection of DIG-labeled hybrids, cultures were rinsed in PBS containing $0.1 \%$ Triton X-100 and $2 \mathrm{mg} / \mathrm{ml} \mathrm{BSA} \mathrm{(PBT),} \mathrm{blocked} \mathrm{with} \mathrm{20 \%} \mathrm{sheep} \mathrm{serum} \mathrm{in} \mathrm{PBT}$ for $6 \mathrm{hr}$, and incubated in sheep anti-DIG-alkaline phosphataseconjugated Fab fragments (Roche Molecular Biochemicals) diluted 1:700 in PBT containing $20 \%$ sheep serum overnight at $4^{\circ} \mathrm{C}$. The next day, cultures were rinsed four times in PBT for 10 min each, rinsed in buffer $2\left(100 \mathrm{~mm}\right.$ Tris, $\mathrm{pH} 9.5,100 \mathrm{~mm} \mathrm{NaCl}$, and $\left.50 \mathrm{mM} \mathrm{MgCl}_{2}\right)$, rinsed in buffer 2 containing $5 \mathrm{~mm}$ levamisole (Sigma), and incubated in buffer 2 containing $5 \mathrm{~mm}$ levamisole, $340 \mu \mathrm{g} / \mathrm{ml}$ nitroblue tetrazolium (Roche Molecular Biochemicals), and $240 \mu \mathrm{g} / \mathrm{ml}$ 5-bromo-4-chloro-3-indolyl phosphate (Roche Molecular Biochemicals) for $30 \mathrm{hr}$. The reaction was

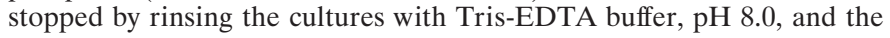
cultures were subsequently processed for NF immunocytochemistry as described previously (Brosenitsch et al., 1998).

Cell counts and statistical analysis. The number of neurons in each culture was estimated by counting all cells within the central $10 \%$ of each coverslip. All cell counts were performed with the investigator blinded to the experimental treatment. Experiments were performed at least three times with at least two cultures per experimental group. At least 1200 neurons per experimental group were scored for TH, Nurr, or pCREB immunoreactivity. Data are presented as the percentage of total neurons that expressed TH protein, TH mRNA, Nurr, or pCREB. The intensity of TH immunoreactivity was measured from randomly chosen fields of cells using SimplePCI imaging software (Compix Inc., Cranberry, PA). Data are presented in arbitrary units with the background subtracted. Intensity was measured on $\sim 1700$ neurons. For statistical analysis, percentages were normalized (arcsin transformation) and values were compared using ANOVA, followed by Duncan's multiple range test. $p<0.05$ was considered significant.

\section{RESULTS}

PG primary sensory neurons provide a robust model for studying activity-dependent neuronal gene expression. We found previously that exposure of fetal PG neurons to chronic depolarizing stimuli in culture leads to a fivefold increase in the percentage of ganglion cells that express dopaminergic traits, including $\mathrm{TH}$, without affecting neuronal survival (Hertzberg et al., 1995; Brosenitsch et al., 1998). In the present study, therefore, we sought to compare induction of dopaminergic traits in response to chronic depolarization and more physiological, patterned, electrical stimuli. Normally, only $10-15 \%$ of PG neurons are dopaminergic (Katz et al., 1983; Finley et al., 1992). Field stimulation of E16.5 PG neurons for $6 \mathrm{hr}$ at either $5 \mathrm{~Hz}$ (a physiological frequency; Bairam et al., 1993) continuously or $25 \mathrm{~Hz}$ for $2 \mathrm{sec}$, once every $10 \mathrm{sec}$, resulted in an approximate sixfold increase in the percentage of neurons expressing $\mathrm{TH}$ protein, an increase identical to that produced by $6 \mathrm{hr}$ of chronic membrane depolarization with elevated $\mathrm{K}^{+}$(Fig. 1). Neuron survival was unaffected 


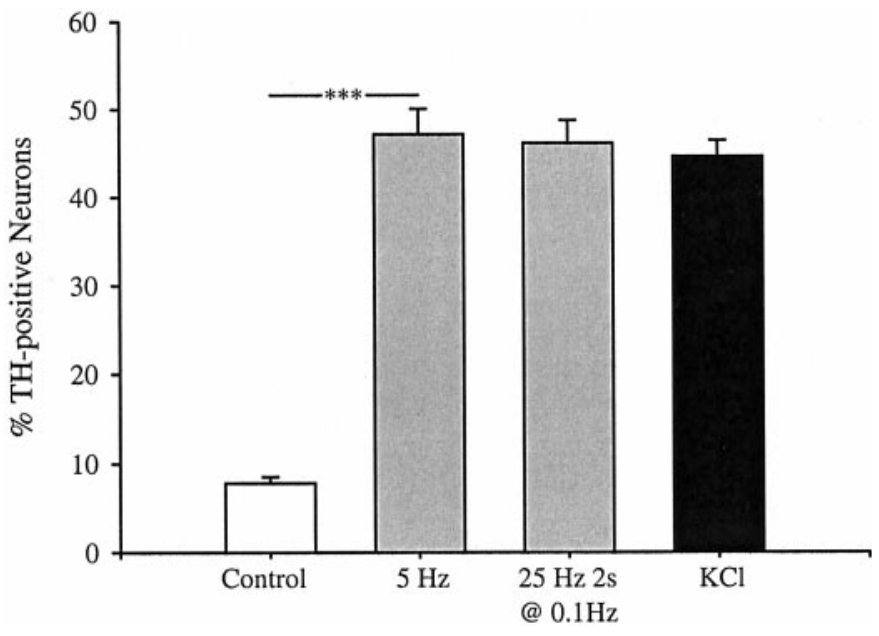

Figure 1. TH induction by electrical stimulation and $\mathrm{K}^{+}$depolarization. Dissociate cultures of E16.5 PG neurons were stimulated at $5 \mathrm{~Hz}$ continuously ( $0.2 \mathrm{msec}$ alternating polarity pulses), at $25 \mathrm{~Hz}$ for $2 \mathrm{sec}$ once every $10 \mathrm{sec}$, or chronically with $40 \mathrm{~mm} \mathrm{KCl}$. After $6 \mathrm{hr}$ of stimulation, neurons were cultured for an additional $12 \mathrm{hr}$ in control conditions and then processed for TH-NF immunocytochemistry. Each bar represents the percentage of total neurons exhibiting TH immunoreactivity. Data are presented as the mean \pm SEM. Comparisons among groups were made using ANOVA followed by Duncan's multiple range test; ${ }^{* * *} p \leq 0.001$.

by either electrical stimulation or $\mathrm{K}^{+}$depolarization (control, $550 \pm 57 ; 5 \mathrm{~Hz}, 428 \pm 32 ; 25 \mathrm{~Hz}, 567 \pm 83 ; \mathrm{KCl}, 536 \pm 37) . \mathrm{In}$ addition, stimulation at $5 \mathrm{~Hz}$, or with elevated $\mathrm{K}^{+}$, for $24 \mathrm{hr}$ significantly increased the percentage of neurons expressing $\mathrm{TH}$ mRNA as determined by in situ hybridization (see Fig. 4). The increase in $\mathrm{TH}$ protein expression after $6 \mathrm{hr}$ of stimulation was prevented by inhibition of mRNA synthesis with $0.5 \mu \mathrm{g} / \mathrm{ml}$ actinomycin $\mathrm{D}$ (Fig. $2 \mathrm{~A}$ ), without affecting neuronal survival (control, $763 \pm 106$ neurons; $5 \mathrm{~Hz}, 662 \pm 55 ; 5 \mathrm{~Hz}$ plus actinomycin, $594 \pm 66)$. Moreover, the effect of $5 \mathrm{~Hz}$ stimulation, but not that of elevated $\mathrm{K}^{+}$, was blocked by the sodium channel antagonist tetrodotoxin $(1.5 \mu \mathrm{M})$, indicating that activation of voltage-gated sodium channels is required for $\mathrm{TH}$ induction by electrical stimulation (Fig. 2B). These initial experiments demonstrated that patterned stimulation and chronic $\mathrm{K}^{+}$depolarization are both effective at inducing TH mRNA and protein in fetal PG neurons.

To establish a semiquantitative measurement of the difference in $\mathrm{TH}$ expression between neurons classified as TH-positive and TH-negative, we measured their fluorescence intensity by digital imaging. In all experimental groups, the average fluorescence intensity of neurons classified as TH-positive was at least six times greater than the average intensity of neurons classified as THnegative (Table 1). Thus, the increase in the percentage of THpositive neurons after $5 \mathrm{~Hz}$ stimulation and $\mathrm{K}^{+}$depolarization reflects highly significant increases in $\mathrm{TH}$ expression per neuron. In addition, these data show that both $5 \mathrm{~Hz}$ stimulation and $\mathrm{K}^{+}$ depolarization induced, on average, a similar level of TH expression per neuron.

We found previously that $68 \%$ of the high voltage-activated calcium current in E16.5 PG neurons is blocked by the N-type channel antagonist $\omega$-conotoxin, whereas only $16 \%$ is blocked by the L-type channel antagonist nimodipine (Brosenitsch et al., 1998). In the present study, we used these antagonists to determine the role of high voltage-activated calcium channels in gene expression induced by patterned electrical stimulation. Inhibition of L-type channels had no effect on the induction of TH protein
A

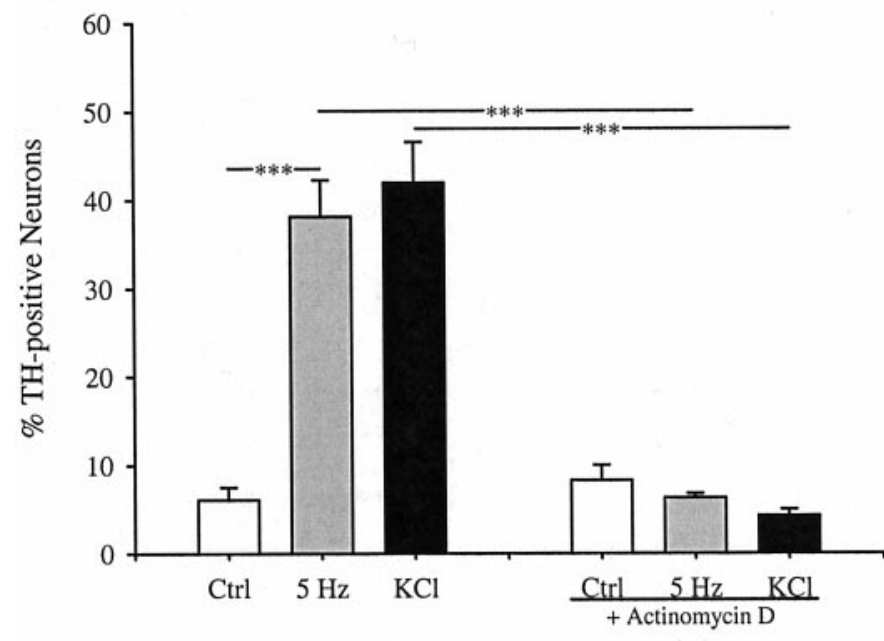

B

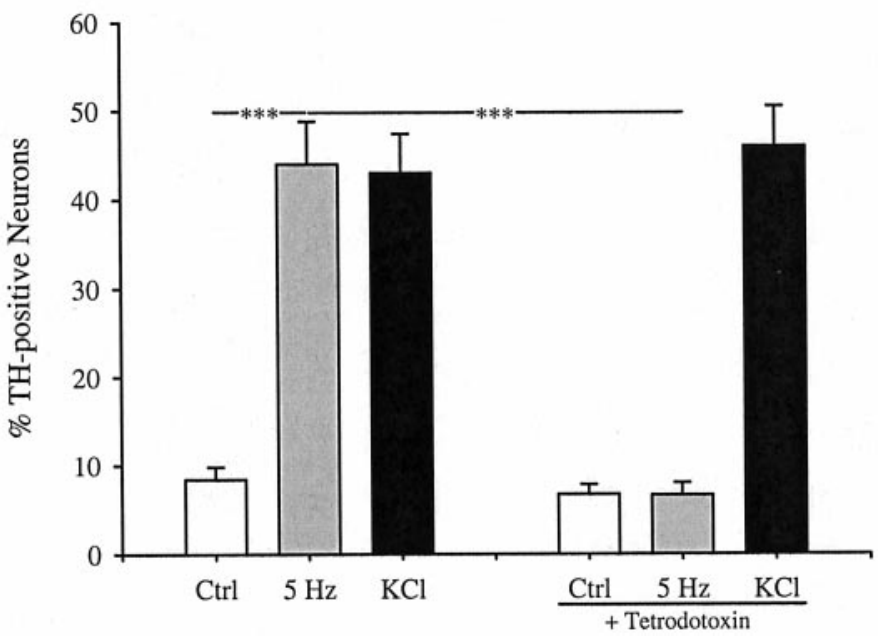

Figure 2. TH induction by electrical stimulation requires mRNA synthesis $(A)$ and functional voltage-activated sodium channels $(B)$. E16.5 PG neurons were stimulated at $5 \mathrm{~Hz}$ or with $40 \mathrm{mM} \mathrm{KCl}$ for $6 \mathrm{hr}$ in the presence or absence of $0.5 \mu \mathrm{g} / \mathrm{ml}$ actinomycin $\mathrm{D}(A)$ or $1.5 \mu \mathrm{M}$ tetrodotoxin $(B)$. Each bar represents the percentage of total neurons exhibiting TH immunoreactivity. Data are presented as the mean \pm SEM. Comparisons among groups were made using ANOVA followed by Duncan's multiple range test; ${ }^{* * *} p \leq 0.001$. Ctrl, Control.

(Fig. 3) or mRNA (Fig. 4) in response to $5 \mathrm{~Hz}$ stimulation but completely blocked induction by chronic $\mathrm{K}^{+}$depolarization, as described previously (Brosenitsch et al., 1998). Conversely, $\mathrm{N}$-type channel blockade completely abolished both $\mathrm{TH}$ protein (Fig. 3) and mRNA (Fig. 4) induction after $5 \mathrm{~Hz}$ stimulation and had no effect on induction by chronic $\mathrm{K}^{+}$depolarization. In addition, nimodipine had no effect on the average fluorescence intensity of TH-positive neurons in $5 \mathrm{~Hz}$ stimulated cultures, and $\omega$-conotoxin had no effect on the average fluorescence intensity of TH-positive neurons in $\mathrm{K}^{+}$-depolarized cultures (Table 1). Thus, nimodipine and $\omega$-conotoxin were not only ineffective in reducing the percentage of $\mathrm{TH}$-positive neurons in $5 \mathrm{~Hz}$ stimulated and $\mathrm{K}^{+}$-depolarized cultures, respectively, but also did not decrease the average level of $\mathrm{TH}$-expression per neuron in these groups. 
Table 1. Fluorescence intensity measurements of neurons classified as TH-positive or TH-negative in control and stimulated cultures, in the absence or presence of calcium channel blockers

\begin{tabular}{lcc} 
& \multicolumn{2}{c}{ Fluorescence intensity $($ mean \pm SEM $)$} \\
\cline { 2 - 3 } Treatment & $\begin{array}{l}\text { TH-Negative cells } \\
(n=732)\end{array}$ & $\begin{array}{l}\text { TH-Positive cells } \\
(n=823)\end{array}$ \\
\hline Control & $5.85 \pm 0.40$ & $60.38 \pm 5.49$ \\
$5 \mathrm{~Hz}$ & $6.83 \pm 0.33$ & $45.72 \pm 3.94$ \\
$\mathrm{KCl}$ & $7.89 \pm 0.45$ & $48.55 \pm 3.95$ \\
$\mathrm{Nimodipine}$ & $9.39 \pm 0.46$ & $72.40 \pm 8.31$ \\
$5 \mathrm{~Hz}+$ nimodipine & $7.20 \pm 0.48$ & $46.86 \pm 4.33$ \\
$\mathrm{KCl}+$ nimodipine & $7.22 \pm 0.39$ & $68.43 \pm 8.61$ \\
$\omega$-Conotoxin & $10.34 \pm 0.45$ & $63.89 \pm 8.03$ \\
$5 \mathrm{~Hz}+\omega$-conotoxin & $6.31 \pm 0.41$ & $49.42 \pm 6.17$ \\
$\mathrm{KCl}+\omega$-conotoxin & $7.33 \pm 0.39$ & $50.98 \pm 4.18$
\end{tabular}

E16.5 PG cultures were stimulated at $5 \mathrm{~Hz}$ or with $40 \mathrm{~mm} \mathrm{KCl}$ for $6 \mathrm{hr}$ in the presence or absence of $1 \mu \mathrm{M} \omega$-conotoxin or $2 \mu \mathrm{M}$ nimodipine. Fluorescence intensity measurements of single cells were obtained as described in Materials and Methods, and the data are expressed in arbitrary units (mean \pm SEM). Between 50 and 135 neurons were analyzed per group. The average fluorescence intensity of cells classified as TH-positive was the same among all treatment groups and was at least sixfold higher than that of cells classified as TH-negative $(p \leq 0.001)$.

To determine whether N-type calcium channels are also required for activity-dependent regulation of other dopaminergic traits, we examined expression of the Nurr family of orphan nuclear receptors using a pan-Nurr antibody that recognizes Nurr1 and Nur77 [nerve growth factor inducible-B (NGFI-B)]. Electrical stimulation $(5 \mathrm{~Hz})$ induced a 10 -fold increase in the percentage of Nurr-immunoreactive neurons that was abolished by N-type channel blockade and unaffected by inhibition of L-type channels (Fig. 5). Elevated $\mathrm{K}^{+}$, on the other hand, produced a 16 -fold increase in the percentage of Nurr-positive cells that was prevented by blockade of L-type calcium channels and unaffected by blockade of N-type channels (Fig. 5). These data indicate, therefore, that patterned electrical stimulation and chronic membrane

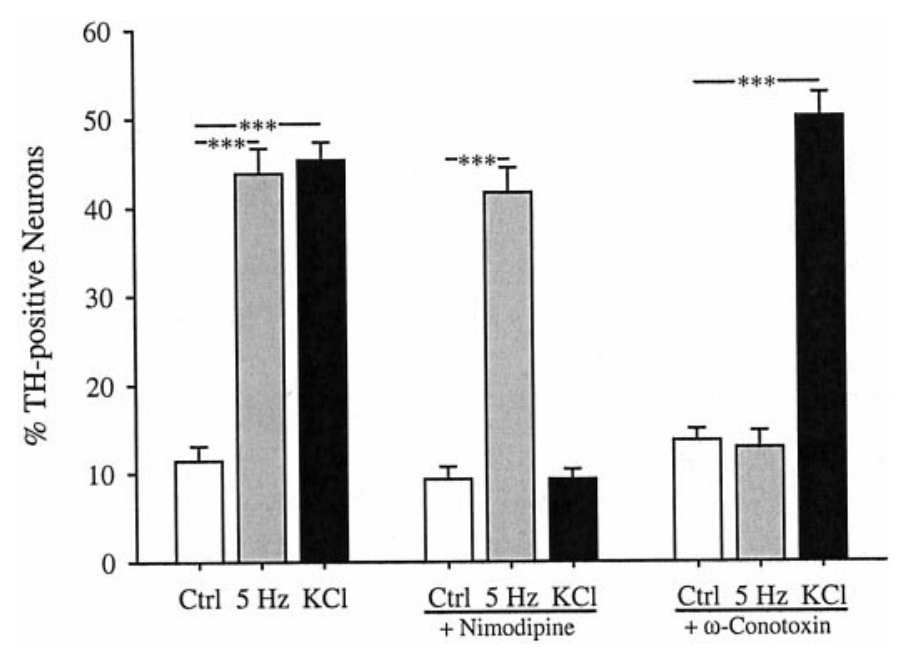

Figure 3. Electrical stimulation $(5 \mathrm{~Hz})$ and $\mathrm{K}^{+}$depolarization induce TH expression by activating distinct calcium channel subtypes. Each bar represents the percentage of total neurons in stimulated and unstimulated $(\mathrm{Ctrl})$ cultures exhibiting TH immunoreactivity in the absence or presence of $2 \mu \mathrm{M}$ nimodipine, an L-type calcium channel antagonist, or $1 \mu \mathrm{M}$ $\omega$-conotoxin, an $\mathrm{N}$-type calcium channel antagonist. Data are presented as the mean \pm SEM. Comparisons among groups were made using ANOVA followed by Duncan's multiple range test; ${ }^{* * *} p \leq 0.001$.
A

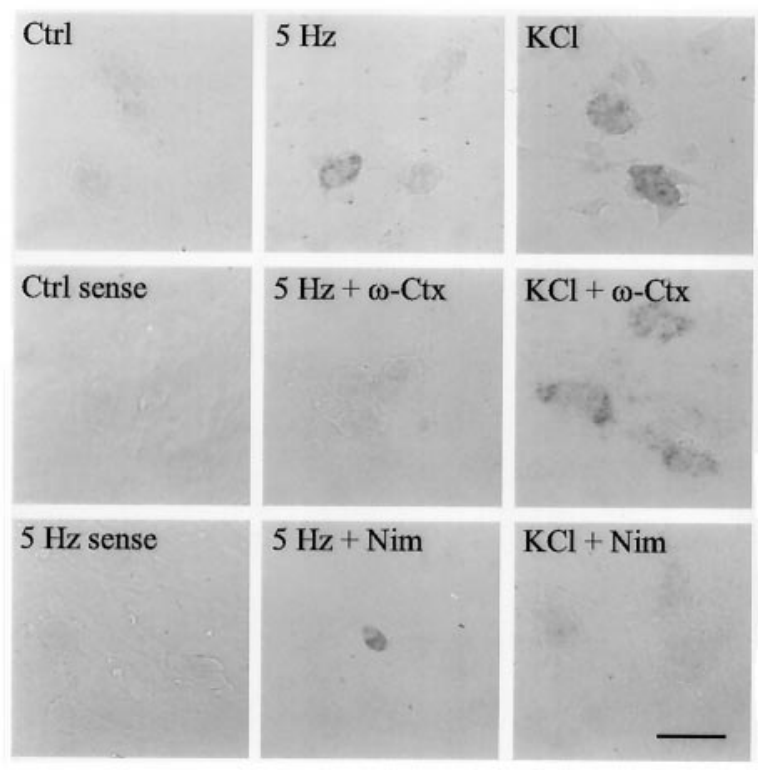

B

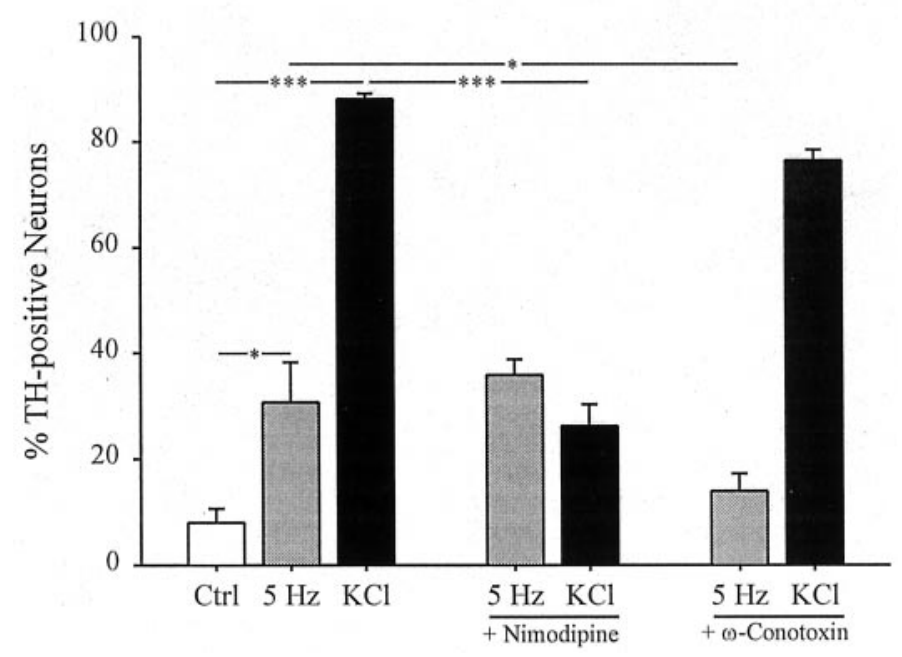

Figure 4. The effect of selective calcium channel antagonists on stimulation-induced expression of TH mRNA. $A$, TH mRNA expression in E16.5 PG cultures stimulated at $5 \mathrm{~Hz}$ or with $40 \mathrm{~mm} \mathrm{KCl}$ for $24 \mathrm{hr}$ in the presence or absence of $1 \mu \mathrm{M} \omega$-conotoxin $(\omega$-Ctx $)$ or $2 \mu \mathrm{M}$ nimodipine (Nim). Scale bar, $50 \mu \mathrm{m}$. B, Each bar represents the percentage of total neurons exhibiting TH mRNA by in situ hybridization. Data are presented as the mean \pm SEM. Comparisons among groups were made using ANOVA followed by Duncan's multiple range test; ${ }^{*} p \leq 0.05 ; * * * p \leq$ 0.001. Ctrl, Control.

depolarization, respectively, induce $\mathrm{TH}$ and Nurr expression by activating distinct populations of voltage-activated calcium channels.

$\mathrm{N}$-type calcium channels have been associated primarily with neurotransmitter release at synaptic sites (Dunlap et al., 1995). This raised the possibility that the $\mathrm{TH}$ and Nurr induction we observed after $5 \mathrm{~Hz}$ stimulation was secondary to electrically evoked transmitter release at synaptic sites that may have developed between PG neurons in our cultures. We considered this unlikely, because primary sensory neurons do not form synapses in vitro in the presence of ganglionic satellite cells (Cooper, 1984; 


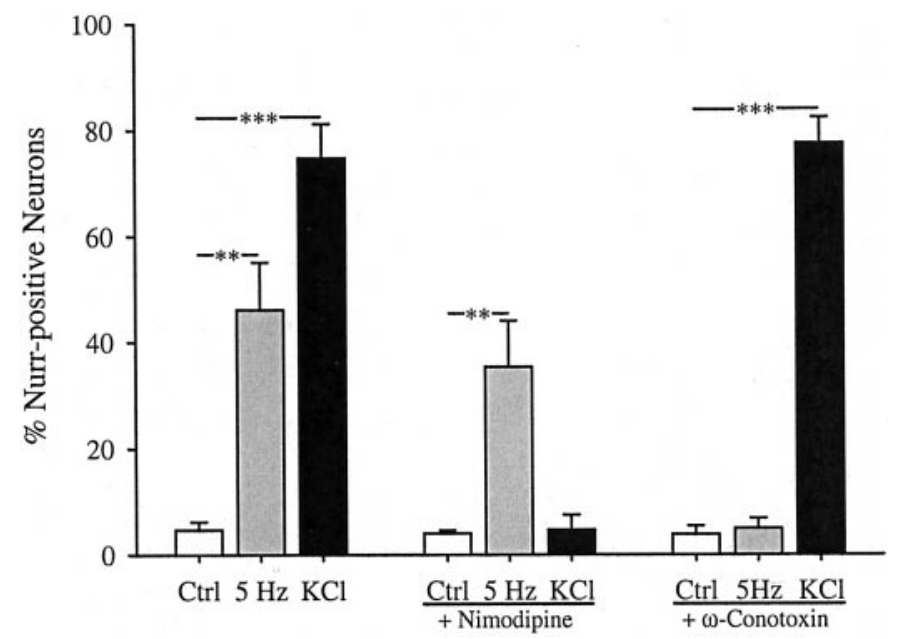

Figure 5. Electrical stimulation $(5 \mathrm{~Hz})$ and $\mathrm{K}^{+}$depolarization induce Nurr expression by activating distinct calcium channel subtypes. Each bar represents the percentage of total neurons in stimulated and unstimulated $(\mathrm{Ctrl})$ cultures exhibiting Nurr immunoreactivity in the absence or presence of $2 \mu \mathrm{M}$ nimodipine or $1 \mu \mathrm{M} \omega$-conotoxin. Data are presented as the mean \pm SEM. Comparisons among groups were made using ANOVA followed by Duncan's multiple range test; ${ }^{* *} p \leq 0.01$; ${ }^{* * *} p \leq 0.001$.

Zhong et al., 1997), as in our cultures. Nonetheless, we compared the effect of $5 \mathrm{~Hz}$ stimulation on $\mathrm{TH}$ expression in the absence and presence of pharmacological blockers of glutamate receptors, because glutamate is the principal excitatory transmitter of PG neurons (Mizusawa et al., 1994). Addition of the NMDA receptor antagonist APV $(50 \mu \mathrm{M})$ and the non-NMDA receptor antagonist CNQX $(10 \mu \mathrm{M})$ had no effect on TH induction by $5 \mathrm{~Hz}$ stimulation (Fig. 6). In addition, application of pertussis toxin $(1 \mu \mathrm{g} / \mathrm{ml})$, to prevent potential transmitter actions through pertussis toxin-sensitive G-protein-linked receptors, had no effect on stimulation-induced TH expression (data not shown). These

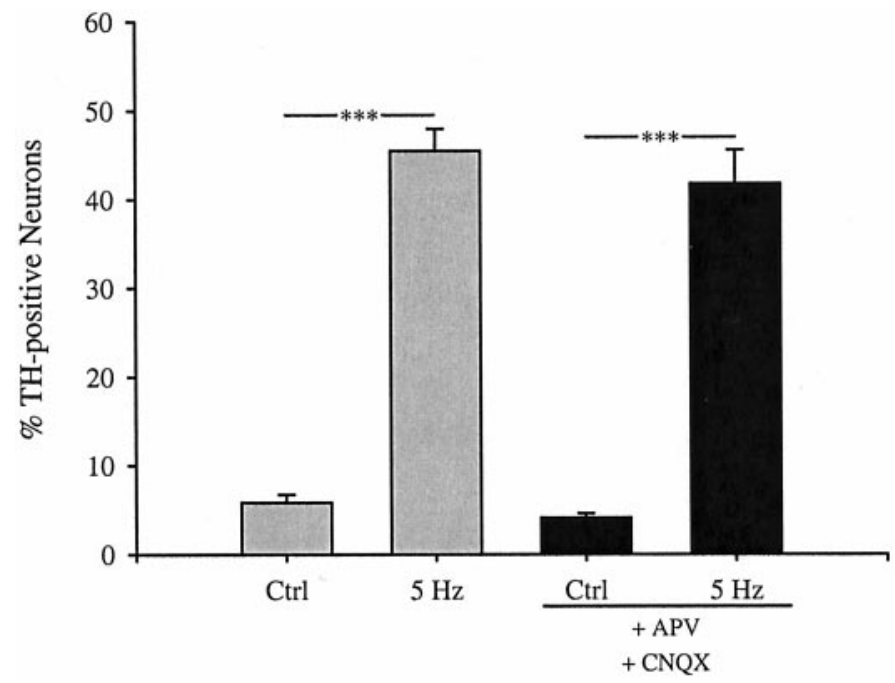

Figure 6. TH induction by $5 \mathrm{~Hz}$ stimulation is unaffected by treatment with ionotropic glutamate receptor antagonists. E16.5 PG neurons were stimulated at $5 \mathrm{~Hz}$ for $6 \mathrm{hr}$ in the presence or absence of the NMDA receptor antagonist APV $(50 \mu \mathrm{M})$ and the non-NMDA receptor antagonist CNQX $(10 \mu \mathrm{M})$. Each bar represents the percentage of total neurons exhibiting TH immunoreactivity presented as the mean \pm SEM. Comparisons were made using ANOVA followed by Duncan's multiple range test; ${ }^{* * *} p \leq 0.001$. Ctrl, Control. data argue strongly against a role for indirect effects of N-type calcium channel activation on activity-dependent TH and Nurr induction in our cultures.

Previous studies demonstrated that different calcium influx sites mediate neuronal gene expression through distinct protein kinase pathways and promoter elements. For example, in hippocampal neurons, calcium entry through either NMDA or L-type channels increases expression of the immediate early response gene $c$-fos; however, CaMK II is required only for $c$-fos induction after activation of L-type channels (Bading et al., 1993). To begin examining whether patterned electrical stimulation and activation of N-type channels induce gene expression through intracellular signaling pathways distinct from those recruited in response to chronic $\mathrm{K}^{+}$depolarization and L-type channel activation, we compared $\mathrm{TH}$ induction by these two protocols in the absence or presence of specific protein kinase inhibitors. Inhibition of PKA with the specific peptide inhibitor $\mathrm{PKI}_{14-22}(50 \mu \mathrm{M})$ (Harris et al., 1997) or PKC with the specific peptide inhibitor PKC-I I $_{19-27}(50$ $\mu \mathrm{M})$ (Eichholtz et al., 1993) resulted in a significant $57 \%$ reduction in the percentage of TH-positive neurons induced by $5 \mathrm{~Hz}$ stimulation but had no effect on $\mathrm{K}^{+}$-induced $\mathrm{TH}$ expression (Fig. 7). A similar result was observed with the structurally distinct PKA antagonist H89 (3 $\mu \mathrm{M}$; data not shown). Conversely, the mitogen-activated protein kinase (MAPK) pathway inhibitor PD98059 (50 $\mu \mathrm{M})$ (Alessi et al., 1995) did not significantly alter TH induction by $5 \mathrm{~Hz}$ stimulation but reduced $\mathrm{TH}$ induction by chronic $\mathrm{K}^{+}$depolarization by $41.5 \%$ (Fig. 7). Inhibition of CaMK II with the specific peptide inhibitor autocamtide-2 inhibitory peptide $(50 \mu \mathrm{M})$ (Ishida et al., 1995) had no effect on TH expression after either $5 \mathrm{~Hz}$ stimulation or $\mathrm{K}^{+}$depolarization (Fig. 7). To rule out the possibility that the PKA and PKC inhibitors decreased the level of $\mathrm{TH}$ expression per neuron in $\mathrm{K}^{+}$depolarized cultures without affecting the percentage of $\mathrm{TH}-$ positive neurons, we measured the fluorescence intensity of $\mathrm{TH}$ positive neurons in these groups. Neither inhibitor significantly altered the average fluorescence intensity of TH-positive neurons in $\mathrm{K}^{+}$-depolarized cultures $(\mathrm{KCl}, 54.3 \pm 5.8, n=56$ neurons; $\mathrm{KCl}$ plus PKA inhibitor, $64.5 \pm 8.3, n=38$ neurons; $\mathrm{KCl}$ plus PKC inhibitor, $51.0 \pm 6.03, n=37$ neurons). Similarly, PD98059 did not significantly alter the average fluorescence intensity of TH-positive neurons in $5 \mathrm{~Hz}$-stimulated cultures $(5 \mathrm{~Hz}, 56.7 \pm$ 9.9, $n=25$ neurons; $5 \mathrm{~Hz}$ plus PD98059, $64.7 \pm 10.1, n=34$ neurons). Moreover, none of the kinase inhibitors significantly affected neuronal survival (Table 2). Together, these data indicate that $\mathrm{TH}$ expression is regulated by distinct protein kinase pathways after patterned electrical stimulation and chronic $\mathrm{K}^{+}$ depolarization, respectively.

The time course of calcium-induced CREB phosphorylation has been shown previously to be dependent on the route by which calcium enters a neuron (Hardingham et al., 1999). To determine whether $\mathrm{K}^{+}$-induced activation of L-type calcium channels and 5 $\mathrm{Hz}$ activation of $\mathrm{N}$-type channels lead to distinct profiles of CREB phosphorylation, we examined expression of pCREB in $\mathrm{PG}$ neurons after $5 \mathrm{~Hz}$ stimulation and $\mathrm{K}^{+}$depolarization for varying periods of time. Both $5 \mathrm{~Hz}$ stimulation and $\mathrm{K}^{+}$depolarization led to a marked increase in the percentage of pCREBexpressing neurons after $15 \mathrm{~min}$ exposure to either protocol (Fig. 8 ). However, $\mathrm{K}^{+}$depolarization produced a sustained increase in the percentage of pCREB-positive neurons that could still be observed after $2 \mathrm{hr}$ of continuous depolarization, whereas pCREB was almost undetectable after $2 \mathrm{hr}$ of continuous $5 \mathrm{~Hz}$ stimulation (Fig. 8). These data demonstrate a dynamic regula- 


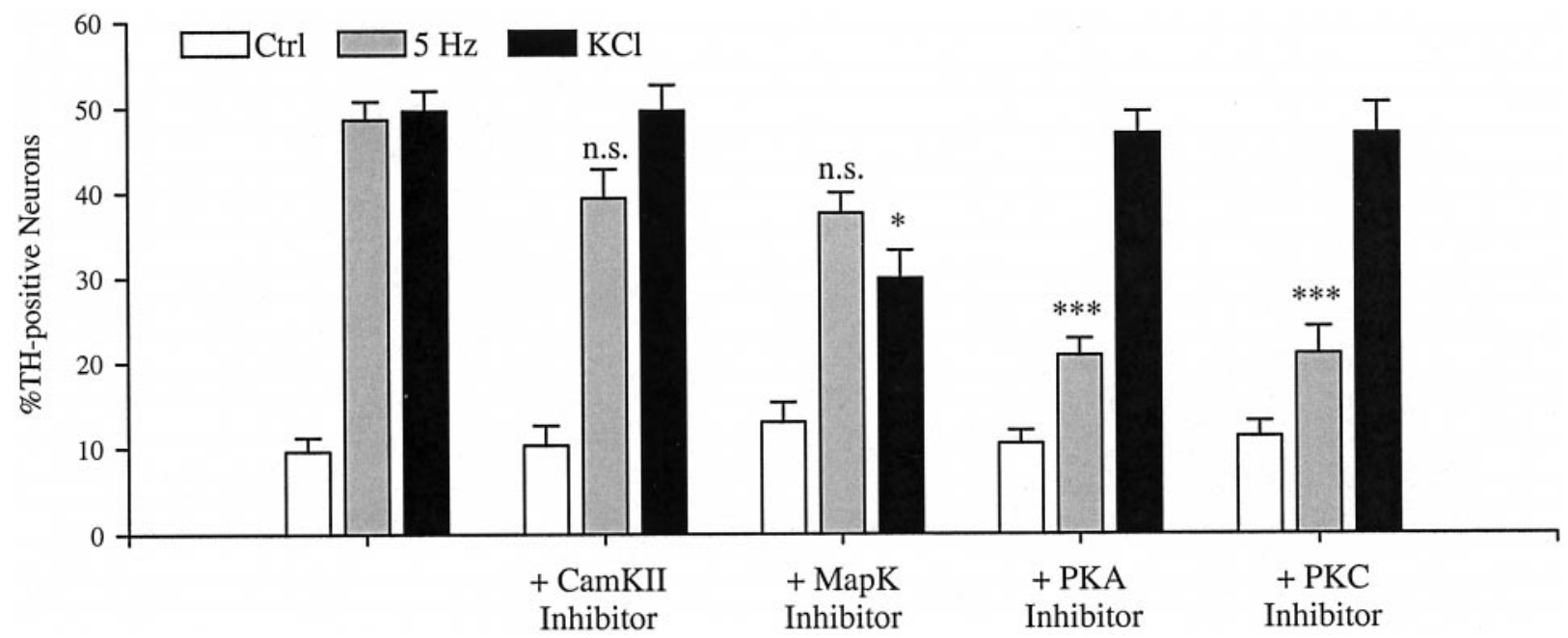

Figure 7. TH induction by $5 \mathrm{~Hz}$ stimulation and potassium depolarization, respectively, requires activation of distinct intracellular kinase pathways. E16.5 PG neurons were stimulated for $6 \mathrm{hr}$ at $5 \mathrm{~Hz}$ (gray bars) or with $40 \mathrm{~mm} \mathrm{KCl}$ (black bars) in the presence or absence of the PKA antagonist PKI ${ }_{14-22}$ amide-myristoylated, the PKC antagonist PKC-I ${ }_{19-27}$-myristoylated, the CaMK II inhibitor autocamtide-2 inhibitory peptide-myristoylated, or the MAPK pathway inhibitor PD98059. Cultures were incubated for $1 \mathrm{hr}$ with each drug $(50 \mu \mathrm{M})$ before stimulation. After stimulation, cultures were grown an additional $12 \mathrm{hr}$ in control conditions. Each bar represents the percentage of total neurons exhibiting TH immunoreactivity presented as the mean \pm SEM. Comparisons were made using ANOVA followed by Duncan's multiple range test; ${ }^{*} p \leq 0.05$ compared with $\mathrm{KCl}$ alone; $* * * p \leq 0.001$ compared with $5 \mathrm{~Hz}$ stimulation alone; n.s., not significantly different from $5 \mathrm{~Hz}$ stimulation alone. Ctrl, Control.

tion of pCREB during patterned stimulation, possibly by phosphatase activity (Bito et al., 1996), which is not seen in response to chronic membrane depolarization.

\section{DISCUSSION}

The present findings demonstrate that calcium influx through N-type channels can directly link phasic electrical stimulation to changes in neuronal gene expression. Although N-type calcium channels have been associated predominately with transmitter release (Dunlap et al., 1995), our results are consistent with the fact that $\mathrm{N}$-type calcium channels carry the majority of the high voltage-activated calcium current in many populations of cells, including primary sensory (Nowycky et al., 1985; Mendelowitz and Kunze, 1992; Brosenitsch et al., 1998) and sympathetic (Hirning et al., 1988; Plummer et al., 1989) neurons, as well as pheo-

\begin{tabular}{|c|c|}
\hline Treatment & Survival/ganglion \\
\hline Control & $624 \pm 43$ \\
\hline $5 \mathrm{~Hz}$ & $609 \pm 46$ \\
\hline $\mathrm{KCl}$ & $613 \pm 40$ \\
\hline AIP & $615 \pm 49$ \\
\hline $5 \mathrm{~Hz}+\mathrm{AIP}$ & $607 \pm 28$ \\
\hline $\mathrm{KCl}+\mathrm{AIP}$ & $664 \pm 23$ \\
\hline PD98059 & $585 \pm 54$ \\
\hline $5 \mathrm{~Hz}+\mathrm{PD} 98059$ & $591 \pm 55$ \\
\hline $\mathrm{KCl}+\mathrm{PD} 98059$ & $639 \pm 57$ \\
\hline $\mathrm{PKI}_{14-22}$ & $650 \pm 40$ \\
\hline $5 \mathrm{~Hz}+\mathrm{PKI}_{14-22}$ & $596 \pm 42$ \\
\hline $\mathrm{KCl}+\mathrm{PKI}_{14-22}$ & $584 \pm 48$ \\
\hline PKC-I ${ }_{19-27}$ & $611 \pm 34$ \\
\hline $5 \mathrm{~Hz}+\mathrm{PKC}-\mathrm{I}_{19-27}$ & $563 \pm 48$ \\
\hline $\mathrm{KCl}+\mathrm{PKC}-\mathrm{I}_{19-27}$ & $614 \pm 53$ \\
\hline
\end{tabular}

Numbers represent the total number of NF-immunoreactive cells per cultured ganglion (mean \pm SEM). AIP, Autocamtide-2 inhibitory peptide. chromacytoma (PC12) cells (Plummer et al., 1989). Moreover, although N-type calcium channels are localized in discrete patches, presumably at synaptic sites, in mature neurons (Westenbroek et al., 1992, 1998; Haydon et al., 1994; Mills et al., 1994), this is not true during early development. Before synaptogenesis, $\mathrm{N}$-type channels are diffusely expressed over the entire neuronal surface (Jones et al., 1989; Bahls et al., 1998). Thus, in immature neurons, N-type calcium channels are required for multiple cellular events, including neuronal migration (Komuro and Rakic,

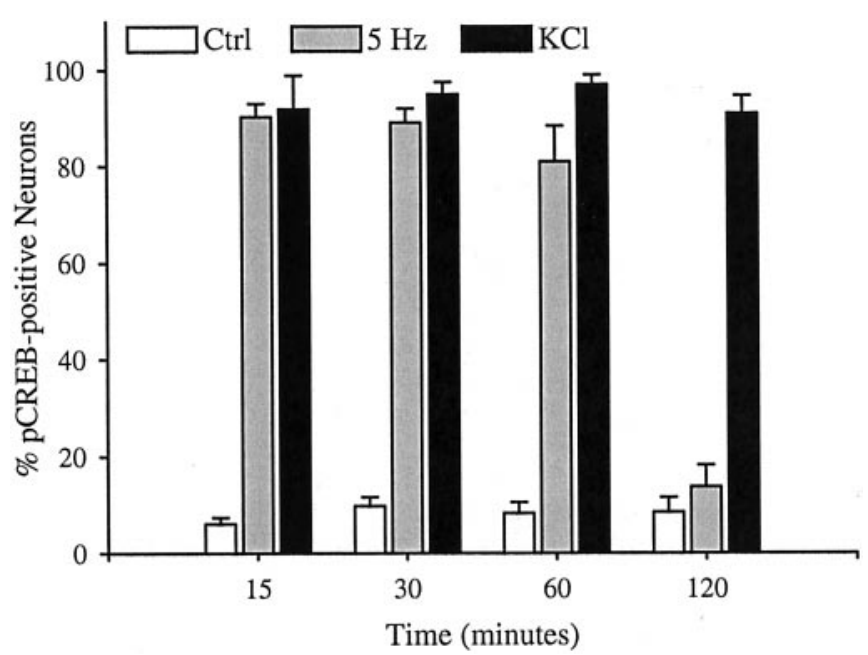

Figure 8. Electrical stimulation $(5 \mathrm{~Hz})$ and potassium depolarization lead to distinct temporal patterns of CREB phosphorylation. E16.5 PG neurons were stimulated at $5 \mathrm{~Hz}$ or with $40 \mathrm{mM} \mathrm{KCl}$ for $15,30,60$, or 120 min. Immediately after the stimulation period, the cultures were fixed and processed for pCREB-NF immunocytochemistry. Each bar represents the percentage of total neurons exhibiting pCREB immunoreactivity. Data are presented as the mean \pm SEM. At each time point, except 120 min, $5 \mathrm{~Hz}$ and $\mathrm{KCl}$ are significantly different from corresponding controls; $p \leq 0.001$. At $120 \mathrm{~min}$, only $\mathrm{KCl}$ is significantly different from control; $p \leq 0.001$. 
1992), axon outgrowth (Doherty et al., 1991), and, as indicated by the present findings, activity-dependent gene expression.

In other neuron types, action potentials, in the absence of synaptic activity, are ineffective at triggering specific intracellular responses, such as TH enzyme activation (Chalazonitis and Zigmond, 1980), CREB phosphorylation (Deisseroth et al., 1996), or c-fos expression (Luckman et al., 1994). For example, Deisseroth and colleagues (1996) demonstrated that CREB phosphorylation induced by patterned stimulation of hippocampal neurons absolutely requires NMDA receptor activation, despite the fact that bulk intracellular and nuclear calcium levels were increased by stimulation alone. This requirement for transynaptic activation has been linked to the fact that L-type calcium channels have relatively slow activation kinetics and are only fully activated by sustained, EPSP-like depolarizations (Nakazawa and Murphy, 1999; Mermelstein et al., 2000), whereas N-type channels are rapidly activating and inactivating (Nowycky et al., 1985; Hirning et al., 1988). In the present study, exposure of sensory neurons to sustained high $\mathrm{K}^{+}$, or rapid, phasic electrical stimuli, induced gene expression by activating $\mathrm{L}$ - and N-type channels, respectively. These findings are consistent with the distinct biophysical properties of L- and N-type channels and supports the hypothesis that their differential activation in vivo allows neurons to distinguish between different types of depolarization (Mermelstein et al., 2000). Specifically, N-type calcium channels could transduce rapid depolarizations, such as those resulting from action potentials, whereas L-type channels would preferentially respond to slow, EPSP-like depolarizations. Our findings demonstrate that these two different temporal patterns of depolarization can be encoded by activation of distinct intracellular signaling pathways. Although our data show that dopaminergic traits are induced in sensory neurons by both chronic and phasic depolarizing stimuli, it is possible that expression of other genes is differentially regulated by activation of $\mathrm{L}$ - and $\mathrm{N}$-type channels, respectively.

Based on previous studies, in which $\mathrm{K}^{+}$depolarization was used to model neuronal activity, the prevailing view has been that activation of L-type calcium channels links membrane depolarization to calcium-induced gene expression. For example, $\mathrm{K}^{+}$induced expression of immediate early genes, such as $c$-fos, requires calcium influx through L-type calcium channels (Morgan and Curran, 1986). In addition, regulation of late response genes, such as transmitter receptor subunits (De Koninck and Cooper, 1995; Gault and Siegel, 1997), transmitter-related proteins (Ai et al., 1998; Brosenitsch et al., 1998; Cigola et al., 1998), ion channels (Schorge et al., 1999), and growth factors (Zafra et al., 1990; Ghosh et al., 1994) by chronic depolarization has been attributed to calcium influx exclusively through L-type calcium channels. However, in these models, N-type channels were most likely inactivated by the level of sustained depolarization produced by chronic $\mathrm{K}^{+}$treatment and thus unable to flux calcium. For example, we found previously that primary sensory neurons treated with $40 \mathrm{~mm} \mathrm{KCl}$ exhibit membrane potentials of approximately $-20 \mathrm{mV}$, a voltage at which $72 \%$ of the total calcium current is inactivated after a $2 \mathrm{sec}$ conditioning pulse (Brosenitsch et al., 1998). This finding suggests that the use of chronic elevated $\mathrm{K}^{+}$ as a model of neuronal activity may generally preclude the ability to assess the role of $\mathrm{N}$-type calcium channels in gene expression. On the other hand, post-translational events, such as TH enzyme activation by short-term $(90 \mathrm{sec})$ exposure to elevated $\mathrm{K}^{+}$, have been shown to require N-type channels (Rittenhouse and Zigmond, 1991, 1999).

Our data indicate that the intracellular signaling cascades re- quired for gene expression in response to patterned electrical stimulation are distinct from those recruited by chronic membrane depolarization. This differential requirement for specific intracellular protein kinases could arise from differences in the amplitude of the cytosolic or nuclear calcium signal (Hardingham et al., 1997; Chawla et al., 1998), the frequency or kinetics of calcium influx (Buonanno and Fields, 1999), or the fact that the route of calcium entry activated by these two stimulation paradigms are distinct (Finkbeiner and Greenberg, 1998). Over the past few years, evidence has accumulated that the route by which calcium enters the cytosol is important for determining which intracellular signaling pathways are recruited and, subsequently, which genes are expressed (Bading et al., 1993; Lerea and McNamara, 1993; Deisseroth et al., 1996; Hardingham et al., 1999; $\mathrm{Hu}$ et al., 1999). For example, $\mathrm{K}^{+}$-induced L-type calcium channel activation in hippocampal neurons leads to sustained pCREB and activation of CREB-binding protein-dependent transcription through a CaMK IV-dependent mechanism, whereas activation of NMDA receptors results in transient pCREB and CamK IV-independent transcription (Hardingham et al., 1999). In addition, $\mathrm{K}^{+}$-induced L-type channel activation in cortical neurons results in transient CaMK II activity and weak PKA activity, whereas NMDA receptor activation produces more sustained CaMK II activity and no PKA activation (Hu et al., 1999). These studies demonstrate clear differences in the intracellular response to activation of two distinct classes of calcium channels, i.e., ligand-gated ionotropic glutamate receptors and voltage-gated L-type calcium channels. Our data indicate that activation of distinct intracellular signaling pathways also occurs when calcium enters through different subtypes of voltage-activated calcium channels. An additional possibility, however, is that the requirement for distinct kinases results from different levels or spatial patterns of calcium influx produced by each stimulation paradigm. For example, Hardingham and colleagues (1997) demonstrated that an increase in nuclear calcium is required for CRE-mediated transcription in response to L-type channel activation, whereas an increase in cytoplasmic calcium, in the absence of nuclear calcium elevation, is not sufficient to induce CRE-mediated transcription, although serum response element-dependent transcription is maintained. Thus, stimuli sufficient to elevate nuclear calcium could induce gene expression through mechanisms that are distinct from stimuli that produce only local cytoplasmic elevations in intracellular calcium.

Previous studies examining the role of kinases in calciumactivated gene expression have implicated numerous intracellular cascades in this process depending on the cell type, stage of development, and type of stimulation. Our data indicate that at least two kinases, PKA and $\mathrm{PKC}$, are required for $\mathrm{TH}$ induction by patterned stimulation of fetal primary sensory neurons. PKA can be activated by intracellular calcium influx and has been implicated previously in calcium-induced gene expression in primary neurons, as well as PC12 cells (Ginty et al., 1991; Thompson et al., 1995). $\mathrm{K}^{+}$-induced TH expression, on the other hand, was independent of PKA and PKC and was only partially attenuated by a MAPK pathway inhibitor, suggesting that kinases other than MAPK, PKA, PKC, and CaMK II are involved. Alternatively, inhibition of one kinase could be compensated for by activation of multiple cascades by calcium influx. For example, depolarization of hippocampal neurons leads to parallel activation of the MAPK pathway, as well as CaMK, each of which is sufficient for maximum CREB phosphorylation (Hardingham et al., 1999). In addition, extensive cross talk between the PKA, PKC, and MAPK 
pathways has been demonstrated (Grewal et al., 1999; Impey et al., 1999). Finally, although our data suggest that CaMK II is not required for activity-dependent $\mathrm{TH}$ induction in sensory neurons, we cannot exclude a role for CaMK IV, which has been localized to the nucleus and can mediate calcium-induced gene expression (Bito et al., 1996; Chawla et al., 1998).

In summary, our findings demonstrate that phasic and chronic depolarizing stimuli induce neuronal gene expression through distinct signaling mechanisms, including activation of different calcium channel subtypes and intracellular kinases. It is possible that the role of $\mathrm{N}$-type calcium channels in gene induction by patterned stimulation is unique to immature neurons in general or to fetal sensory neurons in particular. Nonetheless, the present findings challenge the prevailing view that activation of L-type calcium channels is required for nuclear responses to physiological patterns of neuronal stimulation.

\section{REFERENCES}

Ai X, MacPhedran SE, Hall AK (1998) Depolarization stimulates initial calcitonin gene-related peptide expression by embryonic sensory neurons in vitro. J Neurosci 18:9294-9302.

Alessi DR, Cuenda A, Cohen P, Dudley DT, Saltiel (1995) PD 098059 is a specific inhibitor of the activation of mitogen-activated protein kinase kinase in vitro and in vivo. J Biol Chem 270:27489-27494.

Bading H, Ginty DD, Greenberg ME (1993) Regulation of gene expression in hippocampal neurons by distinct calcium signaling pathways. Science 260:181-186.

Bahls FH, Lartius R, Trudeau LE, Doyle RT, Fang Y, Witcher D, Campbell K, Haydon PG (1998) Contact-dependent regulation of N-type calcium channel subunits during synaptogenesis. J Neurobiol 35:198-208.

Bairam A, Hannhart B, Chone C, Marchal F (1993) Effects of dopamine on the carotid chemosensory response to hypoxia in newborn kittens. Respir Physiol 94:297-307.

Balkowiec A, Katz DM (2000) Activity-dependent release of endogenous brain-derived neurotrophic factor from primary sensory neurons detected by ELISA in situ. J Neurosci 20:7417-7423.

Bito H, Deisseroth K, Tsien RW (1996) CREB phosphorylation and dephosphorylation: a $\mathrm{Ca}^{2+}$ - and stimulus duration-dependent switch for hippocampal gene expression. Cell 87:1203-1214.

Brosenitsch TA, Salgado-Commissariat D, Kunze DL, Katz DM (1998) A role for L-type calcium channels in developmental regulation of transmitter phenotype in primary sensory neurons. J Neurosci 18:1047-1055.

Buonanno A, Fields RD (1999) Gene regulation by patterned electrical activity during neural and skeletal muscle development. Curr Opin Neurobiol 9:110-120.

Chalazonitis A, Zigmond RE (1980) Effects of synaptic and antidromic stimulation on tyrosine hydroxylase activity in the rat superior cervical ganglion. J Physiol (Lond) 300:525-538.

Chawla S, Hardingham GE, Quinn DR, Bading H (1998) CBP: a signalregulated transcriptional coactivator controlled by nuclear calcium and CaM kinase IV. Science 281:1505-1509.

Cigola E, Volpe BT, Lee JW, Franzen L, Baker H (1998) Tyrosine hydroxylase expression in primary cultures of olfactory bulb: role of L-type calcium channels. J Neurosci 18:7638-7649.

Cooper E (1984) Synapse formation among developing sensory neurones from rat nodose ganglia grown in tissue culture. J Physiol (Lond) 351:263-274.

De Koninck P, Cooper E (1995) Differential regulation of neuronal nicotinic ACh receptor subunit genes in cultured neonatal rat sympathetic neurons: specific induction of $\alpha_{7}$ by membrane depolarization through a $\mathrm{Ca}^{2+} /$ calmodulin-dependent kinase pathway. J Neurosci 15:7966-7978.

Deisseroth K, Bito H, Tsien RW (1996) Signaling from synapse to nucleus: postsynaptic CREB phosphorylation during multiple forms of hippocampal synaptic plasticity. Neuron 16:89-101.

Doherty P, Ashton SV, Moore SE, Walsh FS (1991) Morphoregulatory activities of NCAM and N-cadherin can be accounted for by G proteindependent activation of $\mathrm{L}-$ and $\mathrm{N}$-type neuronal $\mathrm{Ca}^{2+}$ channels. Cell 67:21-33.

Dolmetsch RE, Xu K, Lewis RS (1998) Calcium oscillations increase the efficiency and specificity of gene expression. Nature 392:933-936.

Dunlap K, Luebke JI, Turner TJ (1995) Exocytotic Ca ${ }^{2+}$ channels in mammalian central neurons. Trends Neurosci 18:89-98.

Eichholtz T, de Bont DB, de Widt J, Liskamp RM, Ploegh HL (1993) A myristoylated pseudosubstrate peptide, a novel protein kinase C inhibitor. J Biol Chem 268:1982-1986.
Fields RD, Eshete F, Stevens B, Itoh K (1997) Action potentialdependent regulation of gene expression: temporal specificity in $\mathrm{Ca}^{2+}$, cAMP-responsive element binding proteins, and mitogen-activated protein kinase signaling. J Neurosci 17:7252-7266.

Finkbeiner S, Greenberg ME (1998) $\mathrm{Ca}^{2+}$ channel-regulated neuronal gene expression. J Neurobiol 37:171-189.

Finley JC, Polak J, Katz DM (1992) Transmitter diversity in carotid body afferent neurons: dopaminergic and peptidergic phenotypes. Neuroscience 51:973-987.

Gault LM, Siegel RE (1997) Expression of the $\mathrm{GABA}_{\mathrm{A}}$ receptor $\delta$ subunit is selectively modulated by depolarization in cultured rat cerebellar granule neurons. J Neurosci 17:2391-2399.

Ghosh A, Carnahan J, Greenberg ME (1994) Requirement for BDNF in activity-dependent survival of cortical neurons. Science 263:1618-1623.

Ginty DD, Glowacka D, Bader DS, Hidaka H, Wagner JA (1991) Induction of immediate early genes by $\mathrm{Ca}^{2+}$ influx requires cAMPdependent protein kinase in PC12 cells. J Biol Chem 266:17454-17458.

Grewal SS, York RD, Stork PJ (1999) Extracellular-signal-regulated kinase signalling in neurons. Curr Opin Neurobiol 9:544-553.

Gu X, Spitzer NC (1997) Breaking the code: regulation of neuronal differentiation by spontaneous calcium transients. Dev Neurosci 19:33-41.

Hardingham GE, Chawla S, Johnson CM, Bading H (1997) Distinct functions of nuclear and cytoplasmic calcium in the control of gene expression. Nature 385:260-265.

Hardingham GE, Chawla S, Cruzalegui FH, Bading H (1999) Control of recruitment and transcription-activating function of CBP determines gene regulation by NMDA receptors and L-type calcium channels. Neuron 22:789-798.

Harris TE, Persaud SJ, Jones PM (1997) Pseudosubstrate inhibition of cyclic AMP-dependent protein kinase in intact pancreatic islets: effects on cyclic AMP-dependent and glucose-dependent insulin secretion. Biochem Biophys Res Commun 232:648-651.

Haydon PG, Henderson E, Stanley EF (1994) Localization of individual calcium channels at the release face of a presynaptic nerve terminal. Neuron 13:1275-1280.

Hertzberg T, Brosenitsch T, Katz DM (1995) Depolarizing stimuli induce high levels of dopamine synthesis in fetal rat sensory neurons. NeuroReport 7:233-237.

Hirning LD, Fox AP, McCleskey EW, Olivera BM, Thayer SA, Miller RJ, Tsien RW (1988) Dominant role of N-type $\mathrm{Ca}^{2+}$ channels in evoked release of norepinephrine from sympathetic neurons. Science 239:57-61.

Hu SC, Chrivia J, Ghosh A (1999) Regulation of CBP-mediated transcription by neuronal calcium signaling. Neuron 22:799-808.

Impey S, Obrietan K, Storm DR (1999) Making new connections: role of ERK/MAP kinase signaling in neuronal plasticity. Neuron 23:11-14.

Ishida A, Kameshita I, Okuno S, Kitani T, Fujisawa H (1995) A novel highly specific and potent inhibitor of calmodulin-dependent protein kinase II. Biochem Biophys Res Commun 212:806-812.

Jones OT, Kunze DL, Angelides KJ (1989) Localization and mobility of $\omega$-conotoxin-sensitive $\mathrm{Ca}^{2+}$ channels in hippocampal CA1 neurons. Science 244:1189-1193.

Katz DM, Markey KA, Goldstein M, Black IB (1983) Expression of catecholaminergic characteristics by primary sensory neurons in the normal adult rat in vivo. Proc Natl Acad Sci USA 80:3526-3530.

Komuro H, Rakic P (1992) Selective role of N-type calcium channels in neuronal migration. Science 257:806-809.

Lein ES, Shatz CJ (2000) Rapid regulation of brain-derived neurotrophic factor mRNA within eye-specific circuits during ocular dominance column formation. J Neurosci 20:1470-1483.

Lerea LS, McNamara JO (1993) Ionotropic glutamate receptor subtypes activate $c$-fos transcription by distinct calcium-requiring intracellular signaling pathways. Neuron 10:31-41.

Li W, Llopis J, Whitney M, Zlokarnik G, Tsien RY (1998) Cellpermeant caged $\mathrm{InsP}_{3}$ ester shows that $\mathrm{Ca}^{2+}$ spike frequency can optimize gene expression. Nature 392:936-941.

Luckman SM, Dyball RE, Leng G (1994) Induction of $c$-fos expression in hypothalamic magnocellular neurons requires synaptic activation and not simply increased spike activity. J Neurosci 14:4825-4830.

Mendelowitz D, Kunze DL (1992) Characterization of calcium currents in aortic baroreceptor neurons. J Neurophysiol 68:509-517.

Mermelstein PG, Bito H, Deisseroth K, Tsien RW (2000) Critical dependence of cAMP response element-binding protein phosphorylation on L-type calcium channels supports a selective response to EPSPs in preference to action potentials. J Neurosci 20:266-273.

Mills LR, Niesen CE, So AP, Carlen PL, Spigelman I, Jones OT (1994) N-type $\mathrm{Ca}^{2+}$ channels are located on somata, dendrites, and a subpopulation of dendritic spines on live hippocampal pyramidal neurons. J Neurosci 14:6815-6824.

Mizusawa A, Ogawa H, Kikuchi Y, Hida W, Kurosawa H, Okabe S, Takishima T, Shirato K (1994) In vivo release of glutamate in nucleus tractus solitarii of the rat during hypoxia. J Physiol (Lond) 478:55-66. 
Morgan JI, Curran T (1986) Role of ion flux in the control of $c$-fos expression. Nature 322:552-555.

Nakazawa H, Murphy TH (1999) Activation of nuclear calcium dynamics by synaptic stimulation in cultured cortical neurons. J Neurochem 73:1075-1083.

Nowycky MC, Fox AP, Tsien RW (1985) Three types of neuronal calcium channel with different calcium agonist sensitivity. Nature 316:440-443.

Plummer MR, Logothetis DE, Hess P (1989) Elementary properties and pharmacological sensitivities of calcium channels in mammalian peripheral neurons. Neuron 2:1453-1463.

Rittenhouse AR, Zigmond RE (1991) $\omega$-conotoxin inhibits the acute activation of tyrosine hydroxylase and the stimulation of norepinephrine release by potassium depolarization of sympathetic nerve endings. J Neurochem 56:615-622.

Rittenhouse AR, Zigmond RE (1999) Role of N- and L-type calcium channels in depolarization-induced activation of tyrosine hydroxylase and release of norepinephrine by sympathetic cell bodies and nerve terminals. J Neurobiol 40:137-148.

Schorge S, Gupta S, Lin Z, McEnery MW, Lipscombe D (1999) Calcium channel activation stabilizes a neuronal calcium channel mRNA. Nat Neurosci 2:785-790.

Svoboda K, Mainen ZF (1999) Synaptic $\left[\mathrm{Ca}^{2+}\right]$ : intracellular stores spill their guts. Neuron 22:427-430.

Thompson MA, Ginty DD, Bonni A, Greenberg ME (1995) L-type voltage-sensitive $\mathrm{Ca}^{2+}$ channel activation regulates $c$-fos transcription at multiple levels. J Biol Chem 270:4224-4235.

Westenbroek RE, Hell JW, Warner C, Dubel SJ, Snutch TP, Catterall WA (1992) Biochemical properties and subcellular distribution of an N-type calcium channel $\alpha_{1}$ subunit. Neuron 9:1099-1115.

Westenbroek RE, Hoskins L, Catterall WA (1998) Localization of $\mathrm{Ca}^{2+}$ channel subtypes on rat spinal motor neurons, interneurons, and nerve terminals. J Neurosci 18:6319-6330.

Zafra F, Hengerer B, Leibrock J, Thoenen H, Lindholm D (1990) Activity dependent regulation of BDNF and NGF mRNAs in the rat hippocampus is mediated by non-NMDA glutamate receptors. EMBO J 9:3545-3550.

Zhong H, Zhang M, Nurse CA (1997) Synapse formation and hypoxic signalling in co-cultures of rat petrosal neurones and carotid body type 1 cells. J Physiol (Lond) 503:599-612. 